\title{
Implementasi Peraturan Daerah Nomor 6 Tahun 2008 Tentang Pedagang Kaki Lima Terhadap Pembayaran Retribusi PKL di Jember
}

\author{
Cindy Alfin Inayah ${ }^{1}$ dan Ahmad Junaidi
}

${ }^{1}$ Fakultas Syariah, IAIN Jember. E-mail: cindyalfin104@gmail.com

${ }^{2}$ Fakultas Syariah, IAIN Jember. E-mail: ahmadevjunaidinov@gmail.com

\begin{tabular}{l}
\hline Article \\
How to cite: \\
Cindy Alfin Inayah dan \\
Ahmad Junaidi, \\
'Implementasi Peraturan \\
Daerah Nomor 6 Tahun \\
2008 tentang Pedagang \\
Kaki Lima Terhadap \\
Pembayaran Retribusi \\
PKL di Jember' (2020) \\
Vol. 1 No. 3 \\
Rechtenstudent Journal \\
Fakultas Syariah IAIN \\
Jember. \\
Histori artikel: \\
Submit 1 September 2020; \\
Diterima 15 November \\
2020; Diterbitkan 7 \\
Desember 2020. \\
ISSN: \\
2723-0406 (media cetak)
\end{tabular}

\begin{abstract}
In fulfilling their daily needs, of course, everyone has different ways. One of them is by trading. There are many types of trade, but we often encounter street vendors (PKL). The facilities and infrastructure chosen by most of the street vendors are shoulder roads and sidewalks. This is a strategy to attract buyers who pass by in the street area. But on the other hand, it can also interfere with the convenience of road users and pedestrians. Therefore, it is for street vendors who are the attention of the local government. To help street vendors, the Regional Government of Jember Regency drafted and ratified Regional Regulation No. 6 of 2008 concerning Street Vendors. One of the points discussed in the regional regulation is the payment of levies. The purpose of this research is to read and analyze the implementation of payments from street vendors and apply it in Jember Regency. This research is qualitative research with a juridical approach and a sociological approach.
\end{abstract}

Keywords: Street Vendors, Levies, Local Government.

\begin{abstract}
Abstrak
Dalam mencukupi kebutuhan sehari-hari, tentu setiap orang memiliki cara yang berbeda-beda. Salah satunya yaitu dengan cara berdagang. Terdapat banyak jenis perdagangan, akan tetapi yang sering kita dijumpai yakni Pedagang Kaki Lima (PKL). Sarana dan prasarana yang dipilih oleh sebagian besar dari Pedagang Kaki Lima adalah bahu jalan serta trotoar. Hal ini merupakan strategi untuk menarik minat pembeli yang lewat di area jalan tersebut. Namun di sisi lain juga dapat mengganggu kenyamanan pengguna jalan raya dan pejalan kaki. Oleh karena itu Pedagang Kaki Lima seringkali menjadi perhatian bagi pemerintah daerah. Untuk mengatur Pedagang Kaki Lima Pemerintah Daerah Kabupaten Jember membuat dan mengesahkan Peraturan Daerah Nomor 6 Tahun 2008 Tentang Pedagang Kaki Lima. Salah satu poin yang dibahas dalam peraturan daerah tersebut yaitu tentang pembayaran retribusi. Tujuan dari penelitian ini yaitu untuk mengetahui dan menganalisis bagaimana implementasi pelaksanaan kewajiban pembayaran retribusi oleh Pedagang Kaki Lima serta kendala dalam penerapannya di Kabupaten Jember. Penelitian ini merupakan jenis penelitian kualitatif dengan pendekatan yuridis dan pendekatan sosiologis.
\end{abstract}

Kata Kunci: Pedagang Kaki Lima, Retribusi, Pemerintah Daerah.

\section{Pendahuluan}

Dalam kehidupan masyarakat tentunya setiap manusia pasti menginginkan kehidupan yang baik dan layak bagi kesejahteraan keluarganya. Namun pada faktanya tidak semua orang mendapatkan pekerjaan yang sesuai dengan keinginan dan harapannya. Terdapat banyak faktor yang mempengaruhi hal tersebut, baik secara langsung maupun tidak langsung, seperti bekal pendidikan formal yang rendah, keterampilan yang kurang memadai, peningkatan urbanisasi dan lain sebagainya. 
Sedangkan di sisi lain pemenuhan akan kebutuhan primer tidak dapat ditunda dan terus mendesak. Hal inilah yang kemudian mendorong tumbuh suburnya kegiatan ekonomi informal sebagai bentuk alternatif untuk upaya pemenuhan kebutuhan primer yang dikembangkan oleh masyarakat itu sendiri, sehingga mereka yang tidak tertampung di sektor formal terpaksa berpartisipasi pada sektor informal yang biasanya bergerak di bidang jasa dan perdagangan.

Dalam al-Qur'an dijelaskan bahwa manusia pada dasarnya diperbolehkan untuk mengadakan usaha atau transaksi jual beli apa saja untuk memenuhi kebutuhan hidupnya. Allah berfirman:

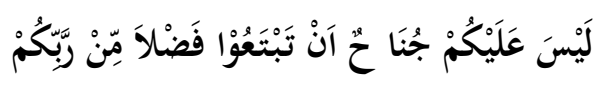

"Tidak ada dosa bagimu untuk mencari karunia (rezeki hasil perniagaan) dari Tuhanmu". ${ }^{1}$

Maka berdasarkan ayat di atas, seseorang tidaklah dipermasalahkan apabila mencari rejeki dengan cara berdagang, sepanjang perdagangan yang ditekuni tidak bertentangan dengan syariat Islam. Termasuk mencari rejeki dalam bentuk profesi berdagang kecil-kecilan di usaha sektor informal.

Salah satu bentuk kegiatan perekonomian yang populer di masyarakat dalam sektor informal adalah Pedagang Kaki Lima (PKL). PKL ada yang menetap pada lokasi tertentu, ada yang bergerak dari tempat satu ke tempat yang lain (menggunakan pikulan, kereta dorong) dengan menjajakan makanan, minuman, dan lainnya secara eceran. PKL pada umumnya bermodal kecil, bahkan terkadang hanya merupakan alat bagi pemilik modal dengan mendapatkan sekedar komisi sebagai imbalan atau jerih payahnya. ${ }^{2}$

Dalam perkembangannya, keberadaan Pedagang Kaki Lima seperti buah simalakama, dibutuhkan tetapi juga menimbulkan permasalahan. Di Kabupaten Jember, Pedagang Kaki Lima sering kali kita jumpai dan tidak sulit untuk mencari keberadaannya. Khususnya adalah di Jalan Jawa. Jalan Jawa merupakan jalan yang paling banyak ditemukan jumlah Pedagang Kaki Lima karena lokasinya yang strategis. Oleh karena itu, sebagai bentuk penertiban, maka aturan terhadap Pedagang Kaki Lima ini harus diadakan dan diterapkan.

Berkaitan dengan hal itu, pemerintah daerah Kabupaten Jember membuat peraturan daerah yang juga tidak terlepas dari aturan pemerintah pusat. Dengan mengeluarkan Perda Nomor 6 Tahun 2008 Tentang Pedagang Kaki Lima. Dalam kaitannya dengan retribusi bagi Pedagang Kaki Lima, pemerintah Kabupaten Jember mengeluarkan Perda Nomor 6 tahun 2008. Perda ini mengatur tentang segala hal yang berkaitan dengan Pedagang Kaki Lima termasuk hak dan kewajiban Pedagang Kaki Lima. Dalam perda ini salah satu yang berkaitan dengan kewajiban Pedagang Kaki Lima adalah membayar retribusi yaitu pada Pasal 8 huruf (e) Perda Nomor 6 Tahun 2008 yang berisi bahwa Pedagang Kaki Lima diharuskan untuk membayar retribusi berdasarkan ketentuan Peraturan Daerah yang berlaku.

Dalam retribusi, apabila diterapkan dengan baik, maka penggunaannya kembali kepada masyarakat Pedagang Kaki Lima dan pemerintah. Karena fungsi dari retribusi ini yaitu adalah pungutan daerah sebagai pembayaran atas jasa atau pemberian izin tertentu yang khusus disediakan dan atau diberikan oleh pemerintah daerah untuk kepentingan orang

\footnotetext{
1 Terjemahan Kementerian Agama RI.

${ }^{2}$ Henny Purwanti dan Misnarti, Usaha Penertiban dan Pembinaan Pedagang Kaki Lima di Kabupaten Lumajang (Sekolah Tinggi Ilmu Hukum), 1.
} 
pribadi atau badan. ${ }^{3}$ Sehingga penggunaannya kembali kepada masyarakat. Akan tetapi, meskipun pemerintah telah mengesahkan Peraturan Daerah Nomor 6 Tahun 2008 Tentang Pedagang Kaki Lima, Pasal 8 huruf e tentang pembayaran retribusi tidak diterapkan sebagaimana mestinya.

\section{Rumusan Masalah}

Adapun permasalahan yang diangkat menjadi pokok masalah sebagai berikut :

1. Bagaimana pelaksanaan pembayaran retribusi oleh Pedagang Kaki Lima di Jalan Jawa Kabupaten Jember berdasarkan Peraturan Daerah Kabupaten Jember Nomor 6 Tahun 2008 tentang Pedagang Kaki Lima?

2. Apa saja problematika dalam penerapan kewajiban pembayaran retribusi terhadap Pedagang Kaki Lima di Jalan Jawa Kabupaten Jember?

\section{Metode Penelitian}

Penelitian ini menggunakan jenis penelitian kualitatif dengan pendekatan yuridis dan pendekatan sosiologis. Pendekatan secara yuridis yaitu menjadikan peraturan sebagai sumber utama bahan penelitian yang kemudian dilihat bagaimana implementasinya di lapangan. Sedangkan pendekatan secara sosiologis yaitu pendekatan secara langsung kepada objek penelitian yang merupakan Pedagang Kaki Lima. Penggalian data dilakukan secara langsung dengan cara melakukan wawancara sehingga bisa mendapatkan data yang lebih akurat, terperinci dan lebih jelas mengenai retribusi Pedagang Kaki Lima di Jalan Jawa Kabupaten Jember.

\section{Hasil dan Pembahasan}

\section{Kebijakan dan Pelaksanaan Pembayaran Retribusi bagi PKL di Jember}

Pada awalnya, istilah Pedagang Kaki Lima hanya ditujukan bagi yang menggunakan gerobak, tetapi kemudian mengalami perkembangan hingga kepada pedagang yang tidak memakai gerobak, sebatas berjualan di pinggir jalan dan tidak menetap, biasanya berjualan di trotoar dan kadang pula juga di emperan toko. ${ }^{4}$ Ada juga pendapat lain yang mengatakan bahwa istilah kaki lima berasal dari zaman rafles "Five Feet" yang berarti jalur pejalan kaki di pinggir jalan selebar lima kaki, yakni ruang yang digunakan untuk kegiatan berjualan pedagang kecil sehingga disebut Pedagang Kaki Lima. ${ }^{5}$ Dalam kawasan Jalan Jawa para pedagang yang tidak menetap juga termasuk dalam kategori istilah Pedagang Kaki Lima tersebut, yang mana dalam kegiatan perdagangannya sehari-hari juga banyak yang terlihat menggunakan bahu jalan dan jalur pejalan kaki.

Untuk mengetahui lebih rinci tentang pedagang yang termasuk dalam kategori Pedagang Kaki Lima terdapat beberapa karakteristik yang perlu dikenali, yakni sebagai berikut6:

\footnotetext{
${ }^{3}$ Marihot Pahala Siahaan, Pajak Daerah E Retribusi Daerah (Jakarta: Raja Grafindo Persada, 2006), 432.

${ }^{4}$ Gilang Permadi, Pedagang Kaki Lima: Riwayatmu dan Nasibmu Kini!, (Jakarta: Yudhistira, 2007), 4.

${ }^{5}$ Retno Widjayanti, Penataan Fisik Kegiatan PKL Pada Kawasan Komersial di Pusat Kota, (Bandung: ITB, Program Pasca Sarjana, 2000) 28.

${ }^{6}$ Suyatno, Bagong dan Kanarji, Kemiskinan dan Kesenjangan Sosial: Ketika Pembangunan Tak Berpihak Pada Rakyat Miskin, (Surabaya: Airlangga University Press, 2005), 47-48.
} 
1. Pola persebaran Pedagang Kaki Lima umumnya mendekati pusat keramaian dan tanpa izin menduduki zona-zona yang semestinya menjadi milik publik.

2. Para Pedagang Kaki Lima umumnya memiliki daya seintensif sosial yang sangat lentur terhadap berbagai tekanan dan kegiatan penertiban.

3. Sebagai sebuah kegiatan usaha Pedagang Kaki Lima umumnya memiliki penyerapan tenaga kerja yang sangat longgar.

4. Sebagian besar Pedagang Kaki Lima adalah kaum migran yang didasari pada ikatan faktor kesamaan daerah asal.

5. Para Pedagang Kaki Lima rata-rata tidak memiliki keterampilan dan keahlian alternatif untuk mengembangkan kegiatan usaha baru di luar sektor informal kota.

Ciri-ciri umum Pedagang Kaki Lima juga dikemukakan oleh Kartono, dkk, sebagai berikut:

1. Merupakan pedagang yang kadang-kadang juga sekaligus berarti produsen.

2. Ada yang menetap pada lokasi tertentu, ada yang bergerak dari tempat yang satu ke tempat yang lain (menggunakan pikulan, kereta dorong, tempat atau stand yang tidak permanen serta bongkar pasang).

3. Menjajakan bahan makanan, minuman, barang konsumsi lainnya yang tahan lama secara eceran.

4. Umumnya bermodal kecil, kadang hanya merupakan alat bagi pemilik modal dengan mendapatkan sekedar komisi sebagai imbalan atau jerih payahnya.

5. Kualitas barang yang diperdagangkan relatif rendah dan biasanya tidak berstandar.

6. Volume peredaran uang tidak seberapa besar, para pembeli umumnya merupakan pembeli yang berdaya beli rendah.

7. Usaha skala kecil bisa berupa family enterprise, dimana ibu dan anak turut membantu dalam usaha tersebut, baik secara langsung maupun tidak langsung.

8. Tawar menawar antara penjual dan pembeli merupakan relasi ciri yang khas pada usaha perdagangan kaki lima

9. Dalam melaksanakan pekerjaannya ada yang secara penuh, sebagian lagi melaksanakan setelah kerja atau pada waktu senggang dan ada pula yang melaksanakan secara musiman.

10.Barang yang dijual biasanya merupakan convenience goods jarang sekali specialty goods.

11.Dan seringkali berada dalam suasana psikologis tidak tenang, diliputi perasaan takut kalau tiba-tiba kegiatan mereka dihentikan oleh Tim Penertiban Umum (TEBUM) dan Satpol PP sebagai aparat pemerintah daerah.

Dari karakteristik-karakteristik di atas, maka padagang yang berada di kawasan Jalan Jawa dengan karakteristik yang serupa termasuk dalam kategori Pedagang Kaki Lima. Jumlah Pedagang Kaki Lima yang berada di sepanjang Jalan Jawa dibagi menjadi dua bagian, yakni sektor informal Pedagang Kaki Lima yang bekerja di waktu siang hari, sedangkan yang kedua yaitu sektor informal Pedagang Kaki Lima yang bekerja di waktu malam hari.7

Adapun sektor informal Pedagang Kaki Lima yang bekerja di siang hari adalah rata-rata sebanyak 65 Pedagang Kaki Lima dan sektor informal Pedagang Kaki Lima yang bekerja pada malam hari rata-rata sebanyak 95 Pedagang Kaki Lima. Jadi total keseluruhan sektor informal Pedagang Kaki Lima di Jalan Jawa baik yang bekerja pada pagi dan malam hari secara

\footnotetext{
${ }^{7}$ Data Hasil Survey dengan Kuisioner (Jember, Januari 2020)
} 
keseluruhan rata-rata mencapai 160 sektor informal Pedagang Kaki Lima. ${ }^{8}$ Adapun untuk sarana yang digunakan Pedagang Kaki Lima juga bermacam-macam, seperti gerobak, pikulan, lapak, tosa, sepeda, dan bangunan semi permanen. ${ }^{9}$ Pedagang yang ada di Jalan Jawa pun kerap kali mendapat pembinaan dari petugas Satpol PP Pemerintah Daerah Kabupaten Jember.

Pemerintah dalam Kamus Bahasa Indonesia adalah badan atau organisasi yang sedang mengurus. ${ }^{10}$ Sedangkan menurut David Apter, pemerintah adalah satuan anggota yang paling umum yang memiliki tanggung jawab tertentu untuk mempertahankan sistem yang mencakup dan monopoli praktis yang menyangkut kekuasaan paksaannya. ${ }^{11}$ Sementara kata "daerah" dalam konteks kebahasaan berarti kesatuan wilayah yang memiliki unsur-unsur khas, yang menjadi pembeda dengan wilayah lain. Untuk unsur pembeda tersebut dapat berupa unsur politis, ekonomi, maupun budaya. Namun dalam konteks ilmu pemerintahan, daerah dapat diartikan sebagai suatu wilayah yang memiliki tata pemerintahan dan administrasi tersendiri.

Dalam Pasal 1 angka 2 Undang-Undang Pemda juga memberikan gambaran umum terkait dengan arti dari pemerintahan daerah, yaitu:

Pemerintahan daerah adalah penyelenggaraan urusan pemerintahan oleh pemerintah daerah dan dewan Perwakilan Rakyat Daerah menurut asas otonomi dan tugas pembantuan dengan prinsip otonomi seluas-luasnya dalam sistem dan prinsip Negara Kesatuan Republik Indonesia Tahun 1945.

Untuk menyelenggarakan pemerintahan daerah, setiap tingkatan daerah memiliki unsur pemerintah daerah yang disebut kepala daerah. Yang mana kepala daerah ini dibantu oleh wakil kepala daerah. Kepala daerah adalah pimpinan eksekutif di lingkungan Pemerintah Daerah. Kepala daerah provinsi adalah gubernur, kepala daerah kabupaten adalah bupati, sedangkan kepala daerah kota adalah walikota. ${ }^{12}$ Pemerintah Daerah Kabupaten Jember adalah bagian dari pemerintahan yang disebutkan di atas, dengan bupati sebagai kepala daerahnya.

Pemerintah Daerah dalam kewenangannya yang bersumber dari peraturan perundangundangan tersebut dapat diperoleh melalui tiga cara yaitu atribusi, delegasi dan mandat. Untuk pengertian dari masing-masing atribusi, delegasi, dan mandat ini H.D. Van Wijk Willem Konijnenbelt mendefinisikan sebagai berikut: ${ }^{13}$

1. Atribusi, yaitu pemberian wewenang pemerintah oleh pembuat Undang-Undang kepada organ pemerintahan.

2. Delegasi, yaitu pelimpahan wewenang pemerintahan dari suatu organ pemerintahan kepada organ pemerintahan lainnya.

3. Mandat, yaitu terjadi ketika organ pemerintahan mengizinkan kewenangannya dijalankan oleh organ lain atas namanya.

Dalam kewenangannya Pemerintah Daerah juga menggunakan prinsip otonomi daerah, secara etimologi otonomi berasal dari bahasa latin, autos berarti sendiri dan nomos yang berarti

\footnotetext{
${ }^{8}$ Survey Peneliti terjun langsung ke Lapangan (Jember, Februari 2020)

${ }^{9}$ Data Hasil Survey dengan Kuisioner (Jember, Januari 2020)

${ }^{10}$ G. Setya Nugraha, R. Maulina F., Kamus Bahasa Indonesia, 146.

${ }^{11}$ Inu Kencana Syafiie, Pengantar Ilmu Pemerintahan (Jakarta: Refika Aditama, 2010), 11.

12 Sirajuddin, Dkk, Hukum Pelayanan Publik, (Malang: Setara Press, 2011), 59.

${ }^{13}$ Ridwan HR, Hukum Administrasi Negara, (Jakarta: PT Raja Grafindo Persada, 2014), 102.
} 
aturan. ${ }^{14}$ Maksud menggunakan prinsip otonomi daerah seluas-luasnya ini mengandung makna bahwa daerah diberi kewenangan membuat kebijakan daerah, untuk memberi pelayanan, peningkatan peran serta, prakarsa, dan pemberdayaan masyarakat yang bertujuan untuk peningkatan kesejahteraan rakyat sesuai dengan potensi dan kekhasan daerah. ${ }^{15}$

Sementara itu dalam asas umum pemerintahan, yang menjadi urusan pemerintahan daerah meliputi hal berikut: ${ }^{16}$

1. Bidang legislasi, yakni atas prakarsa sendiri membuat peraturan daerah dan peraturan kepala daerah yang meliputi perda provinsi Kabupaten /kota. Peraturan kepala daerah meliputi peraturan gubernur dan/atau peraturan bupati/walikota.

2. Masalah perimbangan keuangan antara pemerintah dan pemerintah daerah adalah suatu sistem pembagian keuangan yang adil, proporsional, demokratis, transparan dan bertanggung jawab dalam rangka pendanaan penyelenggaraan dekonsentralisasi dan tugas perbantuan.

3. Perencanaan APBD adalah rencana keuangan tahunan pemerintah daerah yang ditetapkan melalui peraturan daerah.

Dalam bidang legislasi, sebagai daerah otonom, Pemerintah Kabupaten Jember berwenang membuat untuk membuat peraturan daerah untuk melaksanakan urusan otonomi daerah dan tugas pembantuan. Yang mana kemudian peraturan daerah tersebut ditetapkan oleh kepala daerah setelah mendapat persetujuan bersama DPRD.

Oleh karena itu, maka dalam pelaksanaan urusan pemerintah daerah, Pemerintah Kabupaten Jember telah mengesahkan Perda Kabupaten Jember Nomor 6 Tahun 2008 tentang Pedagang Kaki Lima. Termasuk yang diatur dalam perda tersebut Pasal 8 huruf e adalah terkait dengan kewajiban pembayaran retribusi terhadap Pedagang Kaki Lima. Untuk obyek retribusi daerah terdiri dari:

1. Jasa umum, yaitu berupa pelayanan yang disediakan atau diberikan pemerintah daerah untuk tujuan kepentingan dan kemanfaatan umum serta dapat dinikmati oleh orang pribadi atau badan.

2. Jasa usaha, yaitu berupa pelayanan yang disediakan oleh pemerintah daerah dengan menganut prinsip komersial.

3. Perizinan tertentu, yaitu kegiatan tertentu pemerintahan daerah dalam rangka pemberian izin kepada orang pribadi atau badan yang dimaksud untuk pembinaan, pengaturan, pengendalian, dan pengawasan atas kegiatan pemanfaatan ruangan, penggunaan sumber daya alam, barang, prasarana atau sarana guna melindungi kepentingan umum dan menjaga kelestarian lingkungan. ${ }^{17}$

Retribusi yang disebutkan dalam Perda Nomor 6 Tahun 2008 Pasal 8 huruf e tersebut termasuk kedalam retribusi jasa usaha dan merupakan salah satu Pendapatan Asli Daerah, yang dalam pelaksanaannya hanya dipungut oleh pemerintah daerah. Dalam UU PDRD, Pasal 1 angka 64, retribusi daerah adalah pungutan daerah sebagai pembayaran atas jasa atau pemberian izin tertentu yang khusus disediakan dan atau diberikan oleh pemerintah daerah untuk kepentingan orang pribadi atau badan. ${ }^{18}$

\footnotetext{
${ }^{14}$ Victor M. Situmorang dan Cormentyna Sitanggang, Hukum Administrasi Pemerintahan Daerah, (Jakarta: Sinar Grafika, 1994), 60.

${ }^{15}$ Siswanto Sunarno, Hukum Pemerintahan Daerah di Indonesia, (Jakarta: Sinar Grafika, 2012), 8.

${ }^{16}$ Siswanto Sunarno, Hukum Pemerintahan Daerah di Indonesia, 9.

${ }^{17}$ Mardiasmo, Perpajakan (Yogyakarta: CV. Andi Offist, 2008), 14.

${ }^{18}$ Sekretariat Negara RI, Undang-Undang Nomor 28 tahun 2009 tentang Pajak Daerah dan Retribusi Daerah
} 
Dalam mensosialisasikan Peraturan Daerah Nomor 6 Tahun 2008 Tentang Pedagang Kaki Lima, Pemerintah Daerah Jember bersifat terbuka kepada pelaku sektor informal Pedagang Kaki Lima merata di seluruh Kabupaten Jember, termasuk kepada para Pedagang Kaki Lima di Jalan Jawa Jember. Dalam perkembangannya menghadapi Pedagang Kaki Lima di lapangan, Pemerintah Daerah Kabupaten Jember sangat profesionalitas sehingga tidak perlu menimbulkan dampak yang merugikan baik di pihak Pedagang Kaki Lima maupun di pihak Pemerintah Daerah Kabupaten Jember.

Disahkannya Peraturan Daerah Kabupaten Jember Nomor 6 Tahun 2008 tentang Pedagang Kaki Lima ini menjadikan diberlakukannya Peraturan Daerah tersebut untuk setiap subjek yang ditetapkan dalam Peraturan daerah tersebut, yaitu Pedagang Kaki Lima yang bertempat di mana Peraturan daerah itu berlaku, yakni Kabupaten Jember, khususnya dalam kewajiban pembayaran retribusi Pasal 8 huruf e.

Sementara itu, data wawancara yang dilakukan pada bulan Februari 2020, bersama dengan beberapa responden Pedagang Kaki Lima di lapangan, mengungkapkan bahwa tidak adanya penarikan retribusi dari pemerintah. Meskipun telah disahkan Peraturan daerah Nomor 6 Tahun 2008 Tentang Pedagang Kaki Lima, khusus Pasal 8 huruf e yang mewajibkan para Pedagang Kaki Lima untuk dikenakan kewajiban pembayaran retribusi responden Pedagang Kaki Lima berpendapat bahwa tidak pernah ada penarikan pembayaran retribusi Pedagang Kaki Lima di Jalan Jawa Kabupaten Jember.

Hasil kuesioner yang dibagikan pada bulan Januari 2020 juga menyatakan tidak adanya penarikan retribusi Pedagang Kaki Lima di Jalan Jawa. Hasil kuesioner juga menyatakan bahwa sebagian besar tidak tahu adanya Peraturan Daerah Nomor 6 Tahun 2008 Tentang Pedagang Kaki Lima.

Kemudian pada bulan Maret 2020, peneliti juga melakukan wawancara dengan Ibu Malikah selaku Sekretaris di Satuan Polisi Pamong Praja Jember, yang mana mengungkapkan bahwa kawasan jalan Jawa memang tidak diterapkan kewajiban pembayaran retribusi terhadap Pedagang Kaki Lima. Padahal seharusnya, Peraturan Daerah atau Undang-Undang daerah (dalam arti luas), dibuat untuk dan berlaku dalam wilayah daerah otonomi yang bersangkutan. ${ }^{19}$. Hal ini tentu bertentangan dengan Peraturan daerah Nomor 6 Tahun 2008 yang telah disahkan yang mana pada Pasal 8 huruf e mengharuskan kepada Pedagang Kaki Lima untuk membayar retribusi. Akan tetapi pada kenyataannya, pembayaran retribusi kepada Pedagang Kaki Lima di lapangan tidak diterapkan di kawasan Jalan Jawa, padahal pedagang yang ada di kawasan Jalan Jawa tersebut, sudah memenuhi karakteristik Pedagang Kaki Lima.

Jika kembali kepada prinsip otonomi daerah, Pemerintah Daerah berhak untuk mengatur wilayahnya sendiri seluas-luasnya, yang mana maksud dari seluas-luasnya tersebut yakni ini mengandung makna bahwa daerah diberi kewenangan membuat kebijakan daerah, untuk memberi pelayanan, peningkatan peran serta, prakarsa, dan pemberdayaan masyarakat yang bertujuan untuk peningkatan kesejahteraan rakyat sesuai dengan potensi dan kekhasan daerah. ${ }^{20}$

Maka tidak diterapkannya pembayaran retribusi di Jalan Jawa tidak bertentangan dengan Peraturan Daerah Nomor 6 Tahun 2008 tentang Pedagang Kaki Lima Pasal 8 huruf e meskipun disebutkan bahwa setiap Pedagang Kaki Lima diwajibkan untuk membayar

\footnotetext{
${ }^{19}$ Soenobo Wirjosoegito, Proses E Perencanan Peraturan Perundangan, (Jakarta: Ghalia Indonesia, 2004), 36.

${ }^{20}$ Siswanto Sunarno, Hukum Pemerintahan Daerah di Indonesia, 8.
} 
retribusi, sebab poin pertama alasan tidak diberlakukannya aturan tersebut adalah karena daerah kawasan sepanjang Jalan Jawa bukanlah kawasan untuk kegiatan perdagangan, tetapi karena alasan kemanusiaan maka diizinkan dan hanya dilakukan pembinaan dan penyuluhan kepada Pedagang Kaki Lima. Pembayaran retribusi ini hanya dilakukan pada titik tertentu seperti halnya Pasar Tanjung yang memang lokasinya berdekatan dengan pasar.

\section{Problematika Penerapan Pembayaran Retribusi bagi PKL}

Retribusi merupakan salah satu produk yang dimuat dalam Peraturan Daerah Nomor 6 Tahun 2008 Pasal 8 huruf e, maka retribusi yang sudah disahkan melalui Peraturan daerah Nomor 6 Tahun 2008 ini juga harus dijalankan. Dikarenakan retribusi kontra prestasinya langsung dirasakan, maka dari sudut sifat paksaannya lebih mengarah kepada hal yang bersifat ekonomis, artinya apabila seseorang atau badan mau membayar retribusi, maka manfaatnya dapat langsung dirasakan. Akan tetapi, apabila tidak dibayar, maka secara yuridis pelunasannya dapat dipaksakan seperti pajak. ${ }^{21}$ Faktanya di lapangan penerapan pembayaran retribusi tidak diterapkan di kawasan Jalan Jawa. Dan para PKL yang berada di Jalan Jawa tidak dikenakan sanksi.

Berdasarkan hasil wawancara yang dilakukan pada bulan Maret 2020, yang berkaitan dengan problematika dalam pelaksanaan pembayaran retribusi PKL di Jalan Jawa dengan Ibu Malikah selaku Sekretaris di Satuan Polisi Pamong Praja Jember, mengungkapkan bahwa kendala tidak diterapkannya pembayaran retribusi ini yaitu dari berbagai faktor, poin yang pertama yakni dengan alasan bahwa Jalan Jawa sebenarnya bukanlah kawasan yang diizinkan untuk kegiatan sektor perdagangan. Poin kedua, dengan alasan pertimbangan kebutuhan ekonomi masyarakat, poin ketiga yaitu karena pendapatan Pedagang Kaki Lima yang tidak begitu tinggi.

Jika kembali kepada prinsip otonomi daerah yang pertama yakni menggunakan prinsip otonomi seluas-luasnya, yang mana maksud dari seluas-luasnya disini mengandung makna bahwa daerah diberi kewenangan membuat kebijakan daerah, untuk memberi pelayanan, peningkatan peran serta prakarsa dan pemberdayaan masyarakat yang bertujuan untuk peningkatan kesejahteraan rakyat. ${ }^{22}$ Maka alasan-alasan yang dikemukakan tersebut tidak lain kembali kepada prinsip otonomi daerah yang mana tidak dilaksanakan Peraturan Daerah Nomor 6 tahun 2008 tentang Pedagang Kaki Lima Pasal 8 huruf e di Jalan Jawa tersebut yakni demi pemberdayaan masyarakat yang bertujuan untuk peningkatan kesejahteraan rakyat.

Pada kendala poin yang ketiga, yakni karena pendapatan Pedagang Kaki Lima yang tidak begitu tinggi. Hal ini sejalan dengan hasil data kuesioner yang telah dibagikan kepada Pedagang Kaki Lima di Jalan Jawa yang mana hasilnya menyebutkan bahwa pendapatan Pedagang Kaki Lima rata-rata Rp 100.000,- hingga Rp 200.000,- yang mana hasil dari pendapatan ini masih harus dipakai untuk modal kembali.

Van Meter dan Van Horn dalam Winarno menyatakan bahwa implementasi kebijakan publik sebagai tindakan-tindakan yang dilakukan oleh individu-individu atau kelompok pemerintah maupun swasta yang diarahkan untuk mencapai tujuan-tujuan yang telah ditetapkan dalam keputusan-keputusan kebijakan sebelumnya. ${ }^{23}$ Dimana berarti bahwa proses implementasi tidak akan terlaksana sebelum Undang-Undang atau peraturan

\footnotetext{
${ }^{21}$ Wirawan B. Ilyas dan Richard Burton, Hukum Pajak (Jakarta: Salemba Empat, 2004), 5.

22 Siswanto Sunarno, Hukum Pemerintahan Daerah di Indonesia, 8.

${ }^{23}$ Winarno, Teori dan Proses Kebijakan Publik, (Yogyakarta: Media Pressindo, 2002), 102.
} 
ditetapkan serta dana disediakan guna membiayai proses implementasi kebijakan tersebut. Di sisi lain implementasi kebijakan dianggap sebagai fenomena yang kompleks yang mungkin dapat dipahami sebagai proses, output maupun sebagai hasil. ${ }^{24}$ Dalam peraturan perda nomor 6 tahun 2008 tentang Pedagang Kaki Lima pasal 8 huruf e terkait kewajiban pembayaran retribusi dalam pelaksanaannya berguna untuk mengatur Pedagang Kaki Lima. Lebih lanjut lagi tidak berjalannya implementasi Pasal 8 huruf e dalam Peraturan Daerah nomor 6 tahun 2008 tentang Pedagang Kaki Lima ini disebabkan karena beberapa kendala-kendala yang telah disebutkan.

Dalam model implementasi kebijakan, faktor yang mendukung dan menghambat keberhasilan dirumuskan ke dalam empat variabel, yang pertama adalah komunikasi yaitu proses penyampaian informasi kebijakan dari pembuat kebijakan kepada pelaksana kebijakan serta kelompok sasaran kebijakan dan pihak lain yang berkepentingan baik langsung maupun tidak langsung terhadap kebijakan tersebut. ${ }^{25}$ Dalam Pasal 8 huruf e Peraturan Daerah Nomor 6 Tahun 2008 tentang Pedagang Kaki Lima kenyataan di lapangan sebagian besar tidak mengetahui akan adanya perda ini. Dalam sosialisasi tentang peraturan daerah tersebut masih belum sampai kepada masyarakat Pedagang Kaki Lima secara luas. Variabel yang kedua yakni sumberdaya, sumber daya yang perlu dilihat diantaranya sumber daya manusia, sumber daya anggaran, sumber daya fasilitas, sumber daya informasi.

Sumber daya manusia dalam pelaksanaan kebijakan secara jumlah sudah cukup tetapi secara penyebaran informasi secara langsung masih kurang sehingga masih banyak Pedagang Kaki Lima yang masih belum mengetahui. Variabel yang ketiga yaitu disposisi meliputi kemauan, keinginan dan kecenderungan para pelaku kebijakan untuk melaksanakan kebijakan secara sungguh-sungguh sehingga apa yang menjadi tujuan kebijakan dapat diwujudkan. ${ }^{26}$

Dalam pengimplementasian peraturan daerah nomor 6 tahun 2008 tentang Pedagang Kaki Lima diperlukan kerjasama antara dinas satu dengan dinas yang lain dalam pengimplementasian perda ini. Variabel yang terakhir yaitu struktur birokrasi, dalam pengimplementasian perda ini satuan polisi pamong praja sudah mengemban fungsi dan tugasnya masing-masing sehingga proses pelaksanaan kebijakan dari peraturan daerah nomor 6 tahun 2008 telah berjalan meskipun dalam hal pembayaran retribusi Pedagang Kaki Lima tidak dijalankan karena faktor-faktor tertentu.

Untuk mengatasi tidak berjalannya implementasinya Pasal 8 huruf e Peraturan Daerah Nomor 6 Tahun 2008 tentang Pedagang Kaki Lima terkait dengan tidak adanya penarikan retribusi di jalan jawa ini, maka konsekuensi dari tidak adanya penarikan retribusi, pembinaan untuk tidak merusak keindahan kota dan tetap menjaga kebersihan lingkungan terus dilakukan. Selain perluasan lowongan pekerjaan, bagi masyarakat yang belum beruntung dan sulit mencari pekerjaan, maka Pemerintah Kabupaten Jember memberikan peluang berupa sarana dan prasarana kepada masyarakat untuk mencari rejeki guna menghidupi kebutuhan keluarga sehari-hari.

Selain daripada itu, dibolehkannya keberadaan Pedagang Kaki Lima di Jalan Jawa juga menjadi kontribusi dalam pendapatan masyarakat menengah ke bawah. Selain tempatnya yang strategis, hal ini juga menjadikan masyarakat di sekitar Jalan Jawa tidak kebingungan

\footnotetext{
${ }^{24}$ Winarno, Teori dan Proses Kebijakan Publik, 102.

${ }^{25}$ Joko Widodo, Analisis Kebijakan Publik, (Yogyakarta: Media Pressindo, 2013), 97.

${ }^{26}$ Joko Widodo, Analisis Kebijakan Publik, 104.
} 
untuk mencari barang-barang yang dibutuhkan apalagi dengan harga yang terjangkau oleh masyarakat menengah ke bawah.

Untuk saat ini di Jalan Jawa, seperti halnya perbaikan jalan, penerangan dan keamanan didapatkan dari pemerintah daerah langsung, dengan timbal baliknya sektor informal Pedagang Kaki Lima menjaga kepercayaan dari Pemerintah Daerah menertibkan diri dan ikut menjaga kebersihan lingkungan, meskipun hal ini mengakibatkan hilangnya pendapatan daerah dari sektor retribusi Pedagang Kaki Lima.

\section{Kesimpulan}

Kewajiban pembayaran retribusi oleh PKL di Jember diatur dalam Perda Nomor 6 Tahun 2008 tentang Pedagang Kaki Lima. Namun PKL yang berlokasi di Jalan Jawa Kabupaten Jember tidak pernah ditagih untuk membayar retribusi oleh pihak Pemerintah Daerah Kabupaten Jember, meskipun telah diatur pada Pasal 8 huruf e tentang pembayaran retribusi bagi Pedagang Kaki Lima. Pembayaran retribusi hanya dilakukan di titik tertentu seperti Pasar Tanjung.

Problematika penerapan Pasal 8 huruf e Peraturan Daerah nomor 6 tahun 2008 terhadap PKL di Jalan Jawa Jember dikarenakan adanya beberapa kendala, yakni yang pertama karena Jalan Jawa bukanlah kawasan yang diizinkan untuk sektor perdagangan, alasan kedua yakni karena pertimbangan kebutuhan ekonomi masyarakat, alasan ketiga yakni karena pendapatan Pedagang Kaki Lima yang tidak begitu tinggi. Dengan melihat prinsip otonomi, maka hal ini tidak bertentangan sebab memperhatikan pemberdayaan masyarakat yang bertujuan untuk peningkatan kesejahteraan rakyat dengan tetap melakukan pembinaan secara terus menerus.

\section{Daftar Pustaka}

\section{Buku}

Ilyas, Wirawan B. dan Richard Burton. 2004. Hukum Pajak. Jakarta: Salemba Empat.

Mardiasmo. 2008. Perpajakan. Yogyakarta: CV. Andi Offist.

Nugraha, G. Setya. R. Maulina F., Kamus Bahasa Indonesia. (Surabaya: Karina)

Permadi, Gilang. 2007. Pedagang Kaki Lima: Riwayatmu dan Nasibmu Kini!. Jakarta: Yudhistira.

Purwanti, Henny dan Misnarti. Usaha Penertiban dan Pembinaan Pedagang Kaki Lima di Kabupaten Lumajang. (Sekolah Tinggi Ilmu Hukum)

Ridwan HR. 2014. Hukum Administrasi Negara. Jakarta: PT Raja Grafindo Persada.

Siahaan, Marihot Pahala. 2006. Pajak Daerah \& Retribusi Daerah. Jakarta: Raja Grafindo Persada. Sirajuddin, Dkk. 2011. Hukum Pelayanan Publik. Malang: Setara Press.

Situmorang, Victor M. dan Cormentyna Sitanggang. 1994. Hukum Administrasi Pemerintahan Daerah. Jakarta: Sinar Grafika.

Suyatno, Bagong dan Kanarji. 2005. Kemiskinan dan Kesenjangan Sosial: Ketika Pembangunan Tak Berpihak Pada Rakyat Miskin. Surabaya: Airlangga University Press.

Syafiie, Inu Kencana. 2010. Pengantar Ilmu Pemerintahan. Jakarta: Refika Aditama.

Sunarno, Siswanto. 2012. Hukum Pemerintahan Daerah di Indonesia. Jakarta: Sinar Grafika.

Widjayanti, Retno. 2000. Penataan Fisik Kegiatan PKL Pada Kawasan Komersial di Pusat Kota. ITB: Program Pasca Sarjana.

Widodo, Joko. 2013. Analisis Kebijakan Publik. Yogyakarta: Media Pressindo. Winarno. 2002. Teori dan Proses Kebijakan Publik. Yogyakarta: Media Pressindo 
Wirjosoegito, Soenobo. 2004. Proses \& Perencanan Peraturan Perundangan. Jakarta: Ghalia Indonesia.

\section{Perundang-undangan}

Sekretariat Negara RI, Undang-Undang Nomor 28 tahun 2009 tentang Pajak Daerah dan Retribusi Daerah.

Peraturan Daerah Nomor 6 Tahun 2008 tentang Pedagang Kaki Lima. 